\title{
日本語母語話者の英語の文字音韻変換における 母音文字の処理方法
}

\author{
○山田 惠 \\ (北海道薬科大学薬学部) \\ 阿部 純一 \\ (北海道大学大学院文学研究科) \\ キーワード：文字音韻変換、文字音韻処理方法、CVC 偽単語
}

\begin{abstract}
Graphophonological strategies for recoding vowel letters of CVC nonwords by Japanese readers of English as foreign language

$$
\text { OMegumi YAMADA Jun-ichi ABE }
$$

(School of Pharmacy, Hokkaido Pharmaceutical University) (Graduate School of Letters, Hokkaido University) Key words: phonological recoding, graphophonological strategy, CVC nonword
\end{abstract}

英語において、単語の綴りと発音は、一般的に、VC を単位 として対応する。それゆえ、1 音節の $\mathrm{C}_{1} \mathrm{VC}_{2}$ の綴りでは、母音 文字は、綴り $\mathrm{C}_{1} \mathrm{~V}$ のまとまりとしてではなく、綴り $\mathrm{VC}_{2}$ のま とまりとして認知された場合に、正しい発音で音読されるこ とになる。この綴り $\mathrm{VC}_{2}$ の文字音韻対応関係においては、V の発音は $\mathrm{C}_{2}$ の影響を受け、正則 (regular) 対応(例、king /kin/ における $\mathrm{i} \rightarrow / \mathrm{I} /$ ) か変則 (irregular) 対応 (例、wild /waild/ における $\mathrm{i} \rightarrow / \mathrm{ai} /$ ) かで一定せず、このことが英単語の音読 を困難にしている（e.g.，Treiman et al.，2003）。

日本語母語話者の英単語音読においては、母音文字を正し く変換できないことによる誤答（例、wild/wild/）が顕著で あり、その原因の一つは、 $\mathrm{V}$ を $\mathrm{VC}_{2}$ ではなく $\mathrm{C}_{1} \mathrm{~V}$ の一部として 変換することにある（山田＆阿部，2008）。この文字音韻変 換方法については、CV が日本語母語話者の言語習得において 最も基本的な発音単位であるからであるとの指摘もある（太 田，2005）。はたして日本語母語話者は、英単語の音読に、 CV で分節する方法を、基本的な方略として使用しているので あろうか。あるいは、特定の綴りに対する一時的な音読の方 略として使用しているのであろうか。何れにしても、もし、 彼らが CV を文字音韻変換の方略として使用しているのであ れば、 $\mathrm{C}_{1} \mathrm{VC}_{2}$ の綴りを $\mathrm{C}_{1} \mathrm{~V}$ と $\mathrm{C}_{2}$ に分ける形で表示した $\mathrm{CV} / / \mathrm{C}$ の 綴りに対しては、 $\mathrm{VC}_{2}$ をまとまりとして分割表示した $\mathrm{C} / / \mathrm{VC}$ や、特にまとまりを表示しない CVC の綴りに対してよりも、 素早く反応すると予想される。本研究は、英単語の文字音韻 変換において、日本語母語話者が $\mathrm{CV}$ を単位として使用してい るかを明らかにし、CVCの綴りにおける母音文字 V の処理方 略を探ろうとしたものである。

\section{方法}

参加者. 北海道薬科大学の 1-3 年生 40 名（平均年齢 21.8 歳）が参加した。全員、日本語母語話者であった。

材料． 材料には、Coltheart and Leahy（1992）の 1 音節 の偽単語 (英文字緅り) 20 個を用いた。材料には 2 種類あり、 文字音韻対応関係が正則対応の 10 個の偽単語と、変則対応の 10 個の偽単語であった。それぞれの 10 個の材料には、 5 種類 の $\mathrm{VC}_{2}$ が 2 個ずつ含まれ、これらの 2 個は $\mathrm{C}_{1}$ が異なる $\mathrm{C}_{1} \mathrm{VC}_{2}$ 綴りであった（例、ning と ving）。材料は、上述した CVC と $\mathrm{C} / / \mathrm{VC}$ と $\mathrm{CV} / / \mathrm{C}$ の 3 種類の表示条件で提示された。

手続. 実験は参加者ごとに個別に実施された。参加者は、 PC に接続された 17 インチ TFT ディスプレイに提示される材 料 (CVC、C//VC、 or $\mathrm{CV} / / \mathrm{C})$ を、英単語として、なるべく早 く音読するように教示された。音声は、PCに接続された卓上 マイクで採取された。1 試行では、注視点が $1000 \mathrm{~ms}$ 、次に材 料が $5000 \mathrm{~ms}$ の間提示された。この提示時間内に音読があれ ば、その音声に反応して材料は消え、次の試行の注視点が現 われた。材料は、参加者ごとにランダムな順序で提示された。

参加者の半数の 20 名は、分割表示された $\mathrm{C} / / \mathrm{VC} と \mathrm{CV} / / \mathrm{C}$
の 2 条件の材料を提示され、他の 20 名は CVC の材料を提示さ れた。前者の 20 名には、材料の分割表示位置を取り替えて 2 度の実験が実施された。すなわち、1 度目の実験では、10 個 の $\mathrm{C}_{1} \mathrm{VC}_{2}$ が $\mathrm{CV} / / \mathrm{C}$ 表示条件で提示され、残りの 10 個の $\mathrm{C}_{1} \mathrm{VC}_{2}$ が C//VC 表示条件で提示された。また、1 週間後の 2 度目の 実験では、1 度目の材料すべてが分割表示位置を取り替えた 形で提示された。

\section{結果}

正答としたのは、正則対応偽単語に対しては正則反応、変 則対応偽単語に対しては変則反応であった。正答の音読潜時 が、各参加者について、記録された全音読潜時の標準偏差值 の 3 倍を越えた反応 $(1.0 \%)$ は除外して分析された。参加者 の平均正答率と平均正答音読潜時を表 1 に示す。 $\mathrm{C} / / \mathrm{VC}$ 条件 と $\mathrm{CV} / / \mathrm{C}$ 条件の正答率の差は、正則対応材料の場合でも変則 対応材料の場合でも、有意ではなかった。しかし、平均正答 潜時は、正則対応材料の場合、 $\mathrm{C} / / \mathrm{VC}$ よりも $\mathrm{CV} / / \mathrm{C}$ の方が有 意に速かった $(F(1,19)=5.69, p<.05)$ 。分割表示の 2 条件それぞれと分割表示のない CVC 条件の間での、正答率と 正答潜時の差は、いずれも有意ではなかった。

表 1 異なる材料に対する異なる分割表示条件での音読反応

\begin{tabular}{cccccccc}
\hline & \multicolumn{3}{c}{ 正則対応 } & & \multicolumn{3}{c}{ 変則対応 } \\
\cline { 2 - 3 } \cline { 7 - 8 } & $\mathrm{C} / / \mathrm{VC}$ & $\mathrm{CV} / / \mathrm{C}$ & $\mathrm{CVC}$ & & $\mathrm{C} / / \mathrm{VC}$ & $\mathrm{CV} / / \mathrm{C}$ & $\mathrm{CVC}$ \\
\hline 正答率 & 58.6 & 53.8 & 61.4 & & 21.4 & 18.7 & 25.2 \\
$(\%)$ & $(18.1)$ & $(21.7)$ & $(20.3)$ & & $(13.5)$ & $(13.3)$ & $(18.1)$ \\
正答潜時 & 1574 & 1454 & 1583 & & 1512 & 1571 & 1658 \\
(ms) & $(248)$ & $(247)$ & $(451)$ & & $(546)$ & $(543)$ & $(438)$ \\
\hline
\end{tabular}

注）カッコ内は $S D$ を示す。

\section{考察}

英語母語の大学生を対象とした先行研究では、英語の文字 音韻の対応単位で分割した $\mathrm{C} / / \mathrm{VC}$ の表示は、対応単位での分 割とは異なる $\mathrm{CV} / / \mathrm{C}$ の表示よりも、どのような文字音韻対応 関係の材料においても、反応が速く正答率が高く、このこと から、VC は英語母語話者の基本的な文字音韻変換方法でもあ ることが示されている (e.g., Treiman \& Chafetz, 1987)。 日本語母語の大学生を対象とした本実験では、CV//C か C//VC かの違いは、正則対応の材料でも変則対応の材料でも、文字 音韻変換の正しさにほとんど影響しなかった。一方、分割表 示のない材料 (CVC) では、全体的に反応は遅いが、正しい文 字音韻変換の割合が多くなった。特に、変則の材料では、C//VC に比べても、正しく文字音韻変換した割合が高かった。日本 語母語の大学生は、一般に、CVCの綴りは、心の中で、VC と $\mathrm{CV}$ という、母音文字と子音文字のまとめ方として可能な $2 つ$ の方法を比較し、より英語らしい発音を可能にする方を選択 しながら音読しているのかもしれない。 